International Research Journal of Engineering, IT \& Scientific Research
Available online at https://sloap.org/journals/index.php/irjeis/
Vol. 4 No. 6, November 2018, pages: $44 \sim 54$
ISSN: 2454-2261
https://sloap.org/journals/index.php/irjeis/article/view/340

\title{
Exploration and Collection of Cucumber Mosaic Virus Isolates of Horticultural Plants from Bali
}

\author{
Ni Putu Pandawani ${ }^{a}$ \\ Cokorda Javandira ${ }^{b}$ \\ Farida Hanum $^{c}$
}

\section{Article history:}

Received: 20 July 2018

Accepted: 30 September 2018

Published: 7 November 2018

\section{Keywords:}

Cucumber mosaic virus;

Cucumis sativus;

Cucurbita moschata;

Lycopersum esculentum;

Vigna sinensis;

\begin{abstract}
Information regarding the existence and biological character of CMV isolates from several horticultural plants from Bali is still limited. The results of this research on information are very much needed in the further research and development of science and technology, due to it is known that CMV isolates from different hosts can cause different symptoms of infection or specific symptoms in certain plants. Based on these problems, this research was conducted through exploration, collection, and biological testing of CMV isolates found in several horticultural plants in Bali. Therefore, the existence and biological characteristics of each isolate were known. The results showed that all isolates obtained from the field, as many as 36 isolates, only 18 isolates showed symptoms of $N$. glutinousa. The isolates showed symptoms in $N$. glutinosa plants were isolates from cucumber plants 4 isolates, eggplant 3 isolates, pumpkin 1 isolate, 3 chili isolates, 2 isolates tomatoes, 2 beans isolates, and watermelons 3 isolates. The types of symptoms that appeared varied, i.e., 10 symptomatic mosaic isolates, 4 malformed isolates, and 4 necrotic symptomatic isolates. Detection of I-ELISA using CMV antiserum succeeded in getting 6 positive CMV isolates, i.e., isolates derived from cucumber plants (CMV-MB isolates), eggplant (CMV-TRB isolates) watermelon (CMV-SB isolates), chili (CMV-CB isolates), pumpkin (CMV$\mathrm{LB}$ isolates), and tomatoes (CMV-TB isolates). The results of biological testing of CMV isolates from Bali, mosaic symptoms occurred in the indicator plants Nicotiana glutinosa, Capsicum annuum (big chili), Cucumis sativus (cucumber), Lycopersum esculentum (tomato), and Cucurbita moschata (pumpkin). Severe mosaic symptoms only occurred in Cucumis sativus (cucumber) plants. In Vigna sinensis (long bean) infection CMV-Bali isolates only cause symptoms of malformation and even cause no symptoms.
\end{abstract}

2454-2261 ${ }^{\circledR}$ Copyright 2018. The Author. This is an open-access article under the CC BY-SA license (https://creativecommons.org/licenses/by-sa/4.0/) All rights reserved.

${ }^{a}$ Universitas Mahasaraswati, Denpasar, Indonesia

${ }^{\text {b }}$ Universitas Mahasaraswati, Denpasar, Indonesia

${ }^{c}$ Universitas Mahasaraswati, Denpasar, Indonesia 


\section{Author correspondence:}

Ni Putu Pandawani,

Universitas Mahasaraswati, Denpasar, Indonesia

Ph. +62818558257; Fax: +62361-227019

Email address: pandawaniputu@hotmail.com

\section{Introduction}

Cucumber Mosaic Virus (CMV) is a species of virus originating from genus Cucumovirus, family Bromoviridae (Mochizuki and Ohki, 2012). It is round shape with $30 \mathrm{~nm}$ diameter, has four types of nucleic acids, which is a single-threaded RNA (Palukaitis et al., 1992; Fauquet et al., 2005). CMV is also one of the mosaic disease-causing viruses found in Cucurbitaceae plants. CMV can infect 1200 species in more than 100 families of vegetable and horticulture plants. These characteristics make CMV a wrong plant virus is economically important in commercial plants (Palukaitis et al., 1992). Important economic plants can be infected by CMV are big chili, cayenne pepper, paprika, tomato, cucumber, melon, banana, eggplant, chrysanthemum, lilies, and a number of other ornamental plants (Agrios, 2005).

CMV has a wide host range, its spread in all countries and strains with different biological properties have been reported from various places. CMV has many strains and differences between strains depend on the host type, the symptoms produced, the transmission nature, and other characteristics (Francki et al., 1979; Agrios 2005). The disease symptoms due to CMV infection vary depending on the host species or CMV strain. Therefore, it appears to be a character of the host reaction to CMV infection. Pandawani et al., (2017), in cucumber plants (Cucumis sativus) and other Cucurbitaceae members, CMV infection causes mosaic and dwarf symptoms and reduces fruit quantity and quality. In tomato plants (Lycopersicon esculentum), CMV infections cause mosaic, dwarf, fern leaf reduction (McNab et al., 1983) symptoms. In Capsicum annuum, CMV infections cause mosaic symptoms, blistering, fruit malformations, and together with other viruses (TMV, TEV, PVY, and CVMV) cause symptoms of complex viral infections (curly symptoms).

\section{Materials and Methods}

\section{Exploration of host samples infected viruses}

Virus exploration is conducted on several types of symptomatic horticultural plants infected with the virus. Samples were taken from 9 regencies in Bali, included Jembrana, Buleleng, Tabanan, Badung, Gianyar, Bangli, Klungkung, Karangasem, and Denpasar City. Host plants suspected of being infected with CMV were collected and taken at least three samples from one type of plant in each location. To obtain a variety of isolates with more samples collected were samples that showed different symptoms or virus-specific symptoms, namely mosaic, blistering, necrotic leaves/fruit, and leaf malformations.

\section{Propagation of CMV isolates from different hosts}

Propagation of isolates is conducted through mechanical inoculation of symptomatic host saplings infected with the virus. Mechanical viral inoculation was conducted 1 gram of CMV inoculum plant leaves were crushed in sterile mortal by adding $10 \mathrm{ml}$ of phosphate/phosphate buffer $(1: 10 \mathrm{~b} / \mathrm{v})$ containing $1 \% \beta$-mercaptoethanol $(0,01 \mathrm{M}$, pH 7.0). The sap yan is formed immediately inoculated on $N$. glutinosa plant which is on the surface of the first leaf which has been fully opened, the leaves of which have been sprinkled with carborundum 600 mesh first. The plants that have been inoculated are kept in insect vectors that are resistant to symptoms of the disease. The same symptomatic plants on the CMV isolate source plant in the field were then selected, for further purification of CMV isolates.

\section{Purification of CMV isolates}

Virus purification was conducted through biological testing to select CMV isolates. The plants needed to obtain pure CMV isolates were Nicotiana glutinosa, Cucumis sativus, and Chenopodium amaranticolor. The purification Pandawani, N. P., Javandira, C., \& Hanum, F. (2018). Exploration and collection of cucumber mosaic virus isolates of horticultural plants from Bali. International Research Journal of Engineering, IT \& Scientific Research, 
method of CMV isolates was carried out as follows: a sample from the field that had been propagated in N. glutinosa (the result of point 2.2) was infected with $C$. sativus in the cotyledon section, and then infected with $C$. amaranticolor (repeated three times). Furthermore, the virus obtained was re-inoculated into $N$. glutinosa and $C$. sativus plants. Furthermore, the obtained isolates were maintained on $N$. glutinosa and to ensure that CMV isolates were obtained, serological testing of isolates with the Indirect Enzyme-linked immunosorbent assay was performed (I-ELISA) using serum anti-CMV (AGDIA, USA).

\section{CMV isolates collection through the biological test on indicator plants}

Indicator plants used to study the symptoms of infection by all isolates obtained were plants: C. annuum (big chili), Cucumis sativus (cucumber), L. esculentum (tomato), Solanum melongena (green eggplant), Vigna sinensis (long beans), and Cucurbita moschata (pumpkin). All CMV positive isolates were inoculated on several indicator plants. The differences in isolates are expected to be identified based on differences in symptoms in indicator plants so that CMV isolates collection from several hosts was obtained.

\section{Results and Discussions}

\subsection{Collection of plants infected with viruses in the field}

Isolates collection, as well as symptoms observations that occur in plants, suspected being infected with CMV have been conducted and data obtained are shown in Table 1. Isolates were obtained from the field as many as 36 isolates namely derived from cucumber plants ( 5 isolates), big chili (6 isolates), tomatoes (4 isolates), long beans (4 isolates), watermelon (4 isolates), pumpkin (4 isolates) and melons (4 isolates).

Table 1

Isolates collection and host symptoms suspected being infected with CMV

\begin{tabular}{|c|c|c|c|}
\hline $\begin{array}{l}\text { Origin of isolate } \\
\text { Regency }\end{array}$ & Host plants & $\begin{array}{l}\text { Symptoms host } \\
\text { field }\end{array}$ & Sample Code \\
\hline \multicolumn{4}{|l|}{ 1. Bangli } \\
\hline & cucumber & mosaic & $1 \mathrm{M}$ \\
\hline & long beans & necrotic & $2 \mathrm{~K}$ \\
\hline & eggplant & mosaic & $3 \mathrm{Tr}$ \\
\hline & pumpkin & Malformation & $4 \mathrm{~L}$ \\
\hline \multicolumn{4}{|l|}{ 2. Amlapura } \\
\hline & watermelon & malformation & $5 \mathrm{~S}$ \\
\hline & cucumber & Malformation & $6 \mathrm{M}$ \\
\hline & pumpkin & mosaic & $7 \mathrm{~L}$ \\
\hline & melon & necrotic & $8 \mathrm{Me}$ \\
\hline \multicolumn{4}{|l|}{ 3. Semarapura } \\
\hline & tomato & malformation & $9 \mathrm{~T}$ \\
\hline & chili & mosaic & $10 \mathrm{C}$ \\
\hline & eggplant & necrotic & $11 \mathrm{Tr}$ \\
\hline & watermelon & mosaic & $12 \mathrm{~S}$ \\
\hline \multicolumn{4}{|l|}{ 4. Gianyar } \\
\hline & cucumber & necrotic & $13 \mathrm{M}$ \\
\hline & pumpkin & mosaic & $14 \mathrm{~L}$ \\
\hline & eggplant & Malformation & $15 \mathrm{Tr}$ \\
\hline & tomato & mosaic & $16 \mathrm{~T}$ \\
\hline \multicolumn{4}{|l|}{ 5. Singaraja } \\
\hline & melon & mosaic & $17 \mathrm{Me}$ \\
\hline & chili & malformation & $18 \mathrm{C}$ \\
\hline
\end{tabular}




\begin{tabular}{llll} 
& $\begin{array}{l}\text { eggplant } \\
\text { long beans }\end{array}$ & $\begin{array}{l}\text { mosaic } \\
\text { mosaic }\end{array}$ & $\begin{array}{l}19 \mathrm{Tr} \\
20 \mathrm{~K}\end{array}$ \\
\hline 6. Jembrana & & & \\
\hline & cucumber & malformation & $21 \mathrm{M}$ \\
& watermelon & $\begin{array}{l}\text { necrotic } \\
\text { molonaic }\end{array}$ & $22 \mathrm{~S}$ \\
& chili & necrotic & $23 \mathrm{Me}$ \\
& & & $24 \mathrm{C}$ \\
\hline 7. Tabanan & tomato & malformation & $25 \mathrm{~T}$ \\
& cucumber & mosaic & $26 \mathrm{M}$ \\
& pumpkin & necrotic & $27 \mathrm{~L}$ \\
& chili & mosaic & $28 \mathrm{C}$ \\
\hline 8. Badung & & & \\
& melon & mosaic & $29 \mathrm{Me}$ \\
& chili & motel & $30 \mathrm{C}$ \\
& long beans & malformation & $31 \mathrm{~K}$ \\
tomato & malformation & $32 \mathrm{~T}$ \\
\hline 9. Denpasar & & & \\
\hline & chili & necrotic & $33 \mathrm{C}$ \\
& watermelon & mosaic & $34 \mathrm{~S}$ \\
& eggplant & mosaic & $35 \mathrm{Tr}$ \\
& long beans & motel & $36 \mathrm{~K}$ \\
\hline
\end{tabular}

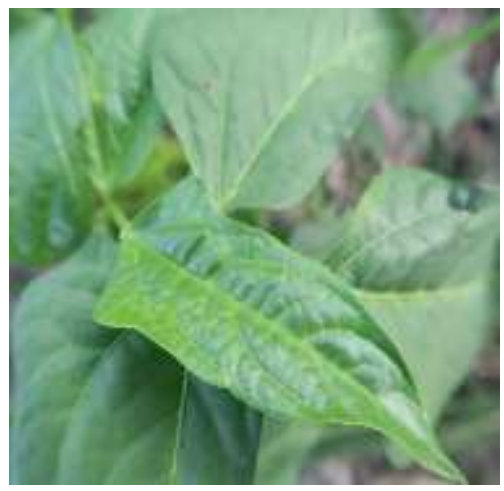

A. Long beans

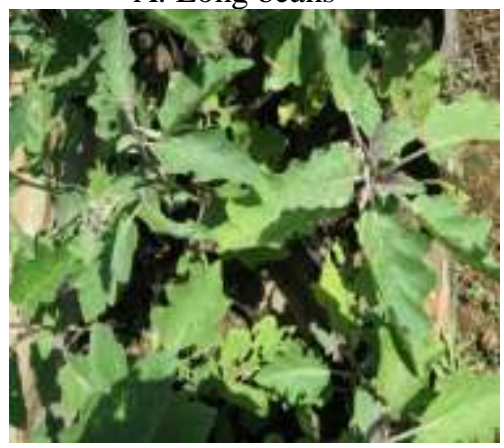

D. Eggplant

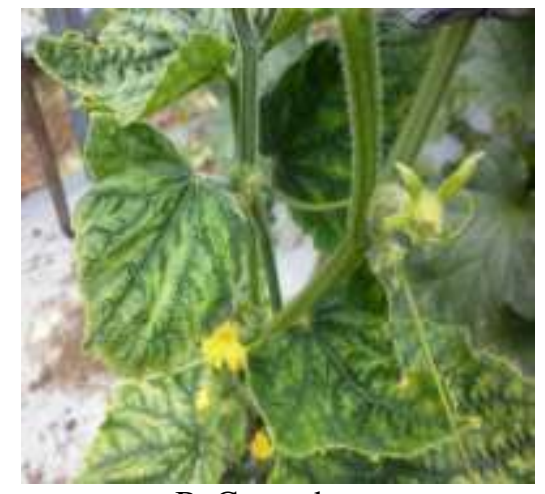

B. Cucumber

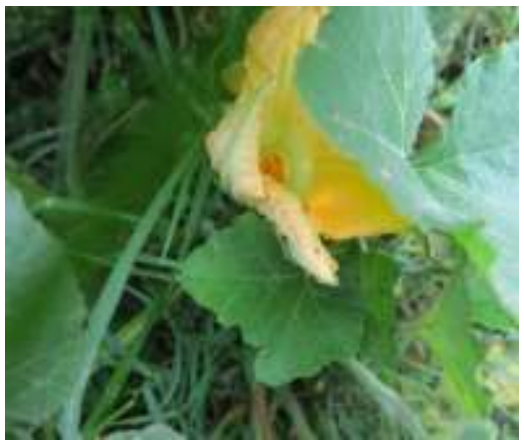

E. Pumpkin

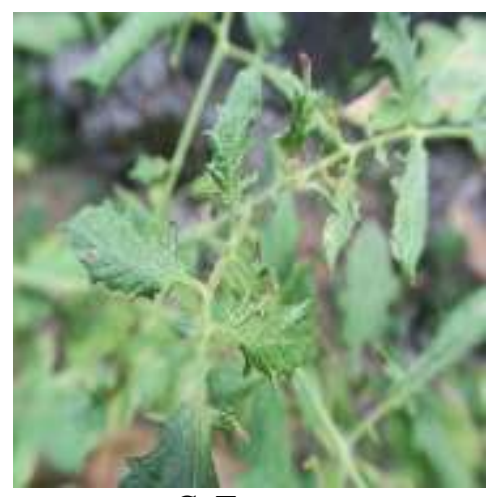

C. Tomato

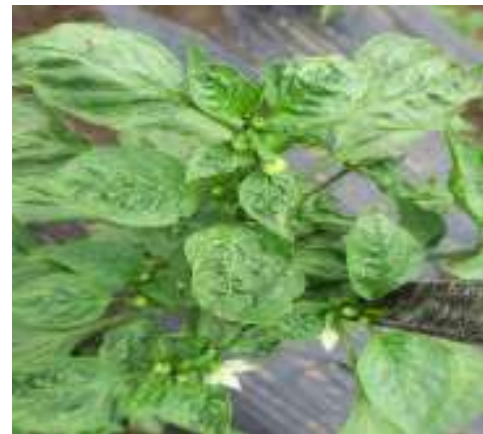

F. Chili

Figure 1. Symptoms of plants in the field suspected being infected with CMV

The plants infected with the virus in the field show complex symptoms, which are infected with several viruses simultaneously. The sample obtained it is expected that there is a single infection by CMV. Symptoms appear in the host plants in the field are suspected of being infected with CMV are very varied or different, ranging from mild to

Pandawani, N. P., Javandira, C., \& Hanum, F. (2018). Exploration and collection of cucumber mosaic virus isolates of horticultural plants from Bali. International Research Journal of Engineering, IT \& Scientific Research, 4(6), 44-54. https://doi.org/10.21744/irjeis.v4n6.340 
severe mosaic, blistering, and leaf malformations (Figure 1). The different symptoms in the same host plant are expected to be obtained by different CMV strains.

\subsection{Purification results of CMV isolates}

The plants are from the field suspected being infected with the virus then purified/conducted purification of the virus with biological techniques to separate CMV from other viruses, using specific indicator plants. All isolates obtained from the field were as many as 36 isolates, after purification only 18 isolates showed symptoms in $N$. glutinousa plants, 18 other isolates did not show symptoms. Isolates who showed symptoms were 10 mosaic symptom isolates, 4 isolates from leaf malformations and 4 isolates from necrotic symptoms. The isolates showing symptoms of $N$. glutinosa were isolates from cucumber plants 4 isolates, eggplant 3 isolates, pumpkin 1 isolate, chili 3 isolates, tomatoes 2 isolates, beans 2 isolates, and watermelons 3 isolates. The incubation period in N. glutinosa plants ranged from 11 days to 15 days after inoculation (Table 2).

Table 2

Type of symptoms in N. glutinosa indicator plants infected with CMV isolates from different hosts

\begin{tabular}{lllll}
\hline No. & $\begin{array}{l}\text { Sample } \\
\text { Code }\end{array}$ & $\begin{array}{l}\text { Original host } \\
\text { field }\end{array}$ & $\begin{array}{l}\text { Incubation } \\
\text { period (hsi) }\end{array}$ & $\begin{array}{l}\text { Symptoms in indicator } \\
\text { plants/N. glutinosa }\end{array}$ \\
\hline 1 & $1 \mathrm{M}$ & cucumber & 12 & mosaic \\
2 & $2 \mathrm{~K}$ & long beans & 14 & necrotic \\
3 & $3 \mathrm{Tr}$ & eggplant & 13 & mosaic \\
4 & $5 \mathrm{~S}$ & watermelon & 11 & malformation \\
5 & $6 \mathrm{M}$ & cucumber & 11 & malformation \\
6 & $10 \mathrm{C}$ & chili & 14 & mosaic \\
7 & $11 \mathrm{Tr}$ & eggplant & 14 & necrotic \\
8 & $13 \mathrm{M}$ & cucumber & 12 & necrotic \\
9 & $14 \mathrm{~L}$ & pumpkin & 13 & mosaic \\
10 & $16 \mathrm{~T}$ & tomato & 14 & mosaic \\
11 & $19 \mathrm{Tr}$ & eggplant & 13 & mosaic \\
12 & $20 \mathrm{~K}$ & long beans & 15 & mosaic \\
13 & $22 \mathrm{~S}$ & watermelon & 13 & mosaic \\
14 & $24 \mathrm{C}$ & chili & 15 & malformation \\
15 & $25 \mathrm{~T}$ & tomato & 12 & malformation \\
16 & $26 \mathrm{M}$ & cucumber & 11 & mosaic \\
17 & $33 \mathrm{C}$ & chili & 15 & necrotic \\
18 & $34 \mathrm{~S}$ & watermelon & 12 & mosaic \\
\hline
\end{tabular}

CMV infects systemically in many plants. Older organ or tissue plants that develop before being infected with the virus are usually not affected by the virus presence, but the young tissue or cells that develop after being infected with the virus are very affected and generally show acute symptoms. Virus symptoms will increase several days after the infection, then decrease to a certain extent or until the plant dies.

\subsection{Serology test results of CMV isolates}

The variation in symptoms caused by CMV will be very difficult to identify only based on the symptoms. In addition, it is also difficult to distinguish other CMV from Cucumovirus isolates (such as Alfalfa mosaic virus, Tomato aspermy virus, and Peanut stunt virus). To further ensure, the virus obtained is CMV, the isolates that have been successfully purified are then tested serologically using I-ELISA test. The isolated sample was expressed positively if the results of the absorbance measurements at $405 \mathrm{~nm}$ wavelength with ELISA reader (Table 3) had a value twice as large as the negative control value (Matthews, 2002). 
Table 3

I-ELISA absorption value at A $405 \mathrm{~nm}$ of CMV isolates

\begin{tabular}{llll}
\hline No. & Sample Code & Origin of the host & $\begin{array}{l}\text { I-ELISA / Antiserum } \\
\text { CMV / absorbance value }\end{array}$ \\
\hline 1 & $1 \mathrm{M}$ & cucumber & 2.524 \\
2 & $2 \mathrm{~K}$ & long beans & 0.522 \\
3 & $3 \mathrm{Tr}$ & eggplant & 2.356 \\
4 & $5 \mathrm{~S}$ & watermelon & 2.584 \\
5 & $6 \mathrm{M}$ & cucumber & 0.620 \\
6 & $10 \mathrm{C}$ & chili & 2.422 \\
7 & $11 \mathrm{Tr}$ & eggplant & 0.426 \\
8 & $13 \mathrm{M}$ & cucumber & 0.524 \\
9 & $14 \mathrm{~L}$ & pumpkin & 2.482 \\
10 & $16 \mathrm{~T}$ & tomato & 0.465 \\
11 & $19 \mathrm{Tr}$ & eggplant & 0.540 \\
12 & $20 \mathrm{~K}$ & long beans & 0.582 \\
13 & $22 \mathrm{~S}$ & watermelon & 0.488 \\
14 & $24 \mathrm{C}$ & chili & 0.522 \\
15 & $25 \mathrm{~T}$ & tomato & 2.528 \\
16 & $26 \mathrm{M}$ & cucumber & 0.642 \\
17 & $33 \mathrm{C}$ & chili & 0.584 \\
18 & $34 \mathrm{~S}$ & watermelon & 0.634 \\
\hline \multicolumn{5}{l}{} & & \\
\hline \multicolumn{5}{l}{ Buffer } & & 0.238 \\
\hline
\end{tabular}

Detection by I-ELISA using CMV antiserum succeeded in getting 6 positive CMV isolates (Figure 2) derived from cucumber plants (CMV-MB isolates), eggplant plants (CMV-TRB isolates) watermelon plants (CMV-SB isolates), chili plants (CMV-CB isolates, pumpkin plants (CMV-LB isolates) and tomato plants (CMV-TB isolates) (Table 4). Other isolates also showed symptoms of $N$. glutinosa appeared to be from CMV I-ELISA test result is not positive.

Pandawani, N. P., Javandira, C., \& Hanum, F. (2018). Exploration and collection of cucumber mosaic virus isolates of horticultural plants from Bali. International Research Journal of Engineering, IT \& Scientific Research, 4(6), 44-54. https://doi.org/10.21744/irjeis.v4n6.340 


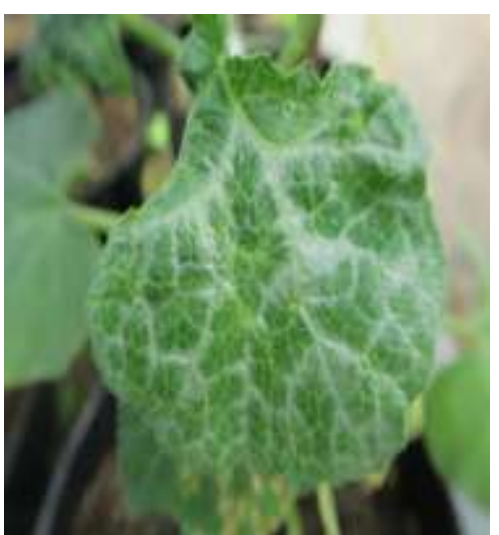

A. Pumpkin Isolate

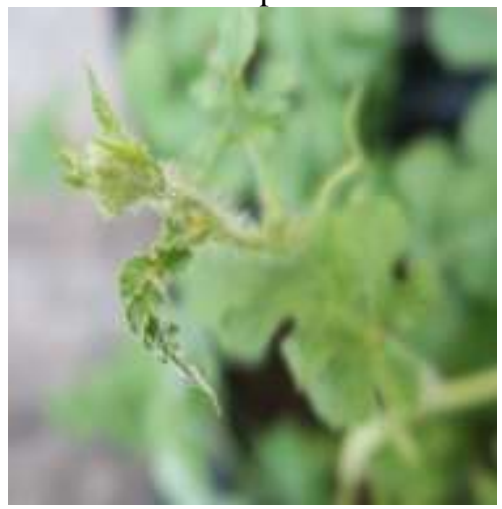

D. Watermelon Isolate

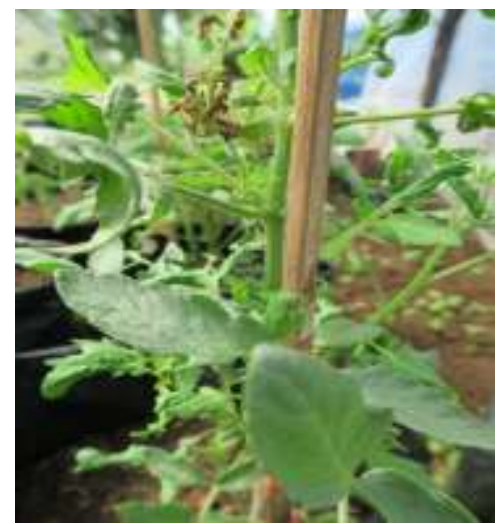

B. Tomato Isolate

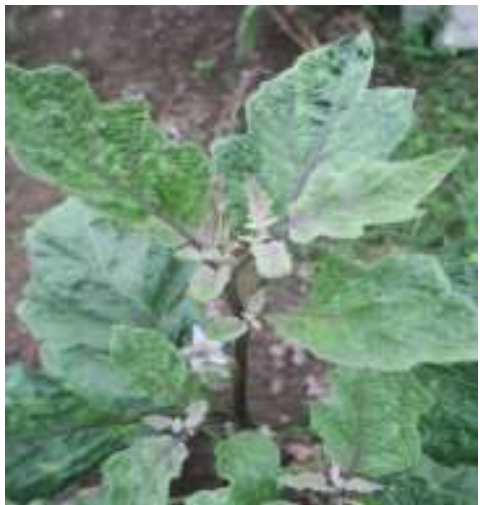

E. Eggplant Isolate

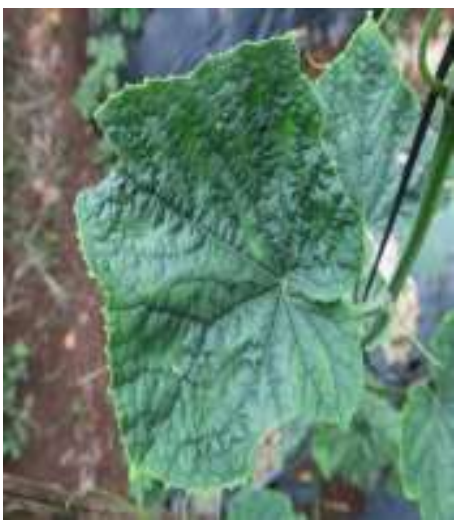

C. Cucumber Isolate

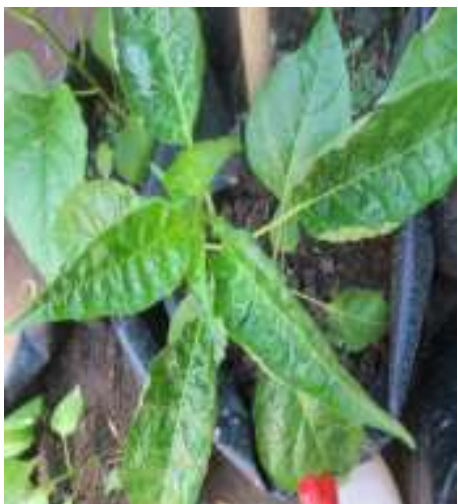

F. Chili Isolate

Figure 2. CMV-Bali isolates

Table 4

CMV positive isolates from different hosts

\begin{tabular}{llllll}
\hline No. & $\begin{array}{l}\text { Sample } \\
\text { code }\end{array}$ & Origin of host & $\begin{array}{l}\text { Symptom type on } \\
\text { indicator plants/N. } \\
\text { glutinosa }\end{array}$ & $\begin{array}{c}\text { I-ELISA } \\
\text { Isolate name } \\
\text { of CMV Bali }\end{array}$ \\
\hline 1 & $1 \mathrm{M}$ & Cucumber & $\begin{array}{l}\text { Mosaic } \\
\text { Malformation }\end{array}$ & + & CMV-MB \\
2 & $3 \mathrm{Tr}$ & eggplant & Malformation & + & CMv-TRB \\
3 & $5 \mathrm{~S}$ & Watermelon & CMV-SB \\
4 & $10 \mathrm{c}$ & Chili & Mosaic & + & CMV-CB \\
5 & $14 \mathrm{~L}$ & Pumpkin & Mosaic & + & CMV-LB \\
6 & $25 \mathrm{~T}$ & Tomatoes & Malformation & + & CMV-TB \\
\hline
\end{tabular}

\subsection{Indicators plant symptoms on the biological test of CMV isolates}

The symptoms result from infection with six CMV isolates from Bali on several important indicator plants are highly varied and some are asymptomatic. It appears varying from 6 days after inoculation to 13 days after inoculation with severe mosaic, mosaic, local malformations, and necrotic symptoms (Table 5). 
Table 5

Symptoms of indicator plants infected with CMV isolates from Bali

\begin{tabular}{|c|c|c|c|c|c|c|}
\hline \multirow[b]{2}{*}{ Indicator plant } & \multicolumn{6}{|c|}{ CMV-Bali Isolates } \\
\hline & CMV-MB & CMV-TRB & CMV-SB & CMV-CB & CMV-LB & CMV-TB \\
\hline \multicolumn{7}{|c|}{ Symptoms } \\
\hline Nicotiana glutinosa & mosaic & malformation & mosaic & mosaic & malformation & mosaic \\
\hline $\begin{array}{l}\text { Capsicum аппиит } \\
\text { (big chili) }\end{array}$ & mosaic & mosaic & malformation & mosaic & mosaic & malformation \\
\hline $\begin{array}{l}\text { Cucumis sativus } \\
\text { (cucumber), }\end{array}$ & $\begin{array}{l}\text { weight } \\
\text { mosaic }\end{array}$ & mosaic & $\begin{array}{l}\text { weight } \\
\text { mosaic }\end{array}$ & asymptomatic & mosaic & mosaic \\
\hline $\begin{array}{l}\text { Lycopersum. } \\
\text { esculentum } \\
\text { (tomato), }\end{array}$ & malformation & malformation & mosaic & mosaic & malformation & malformation \\
\hline $\begin{array}{l}\text { Vigna sinensis } \\
\text { (long beans), } \\
\text { Cucurbita }\end{array}$ & malformation & asymptomatic & asymptomatic & asymptomatic & asymptomatic & malformation \\
\hline $\begin{array}{l}\text { moschata } \\
\text { (pumpkin) }\end{array}$ & mosaic & asymptomatic & malformation & mosaic & mosaic & malformation \\
\hline $\begin{array}{l}\text { Chenopodium } \\
\text { amaranticolor }\end{array}$ & necrotic & necrotic & necrotic & necrotic & necrotic & necrotic \\
\hline
\end{tabular}

In indicator plants, Nicotiana glutinosa isolates CMV-MB, CMV-SB, CMV-CB, and CMV-TB cause mosaic symptoms, whereas other isolates cause symptoms of malformation. In Capsicum annuum (big chili) isolates CMVMB, CMV-TRB, CMV-CB and CMV-LB cause symptomatic mosaics, whereas CMV-SB and CMV-TB isolate cause symptoms of malformation. In Cucumis sativus (cucumber) plants, CMV-MB isolates and CMV-SB showed severe mosaic symptoms, CMV-TRB, CMV-LB, and CMV-TB isolates caused mosaic symptoms while CMV-CB isolates showed no symptoms. In Lycopersum esculentum plants (tomato), CMV-SB and CMV-CB isolate because of mosaic symptoms while CMV-MB, CMV-TRB, CMV-LB, and CMV-TB isolates cause symptoms of malformation. In indicator plants of Vigna sinensis (long bean) isolates CMV-MB and CMV-TB cause symptoms of malformation while CMV-TRB isolates, CMV-SB, CMV-CB, and CMV-LB do not cause symptoms. In the Cucurbita moschata plant (pumpkin), CMV-MB, CMV-CB, and CMV-LB isolate caused mosaic symptoms, CMVSB and CMV-TB isolates caused symptoms of malformation while CMV-TRB isolates showed no symptoms. In Chenopodium amaranticolor plants all isolates cause local necrotic symptoms.

Severe mosaic symptoms only occur in Cucumis sativus (cucumber) plants due to infection with CMV-MB isolates and CMV-SB. Mosaic symptoms occur in indicator plants Nicotiana glutinosa (due to infection with CMVMB, CMV-SB, CMV-CB, and CMV-TB isolates), in Capsicum annuum plants (big chili) (due to infection with CMV-MB isolates, CMV-TRB), CMV-CB and CMV-LB, in Cucumis sativus (cucumber) plants, (due to CMVTRB, CMV-LB and CMV-TB isolates), in Lycopersum esculentum (tomato) plants (due to CMV-SB and CMV isolates) -CB), in Cucurbita moschata (pumpkin) plants (due to infection with CMV-MB, CMV-CB and CMV-LB isolates) In Vigna sinensis (long bean) infection CMV-Bali isolates did not cause mosaic symptoms, only caused symptoms of malformations (due to infection with CMV-MB and CMV-TB isolates) and even CMV isolates from Bali, namely CMV-TRB isolates, CMV-SB, CMV-CB, and CMV-LB did not cause symptoms.

\section{Conclusion}

1. Exploration of all isolates from the field as many as 36 isolates, and only 18 isolates showed symptoms in $N$. glutinousa plants. The isolates showed symptoms in $N$. glutinosa plants were isolates from cucumber plants 4 isolates, eggplant 3 isolates, pumpkin 1 isolate, 3 chili isolates, 2 isolate tomatoes, 2 bean isolates, and 3 watermelon isolates. The symptoms types appear vary, 10 of which are symptomatic mosaic, 4 are symptomatic malformations, and 4 necrotic symptomatic isolates.

Pandawani, N. P., Javandira, C., \& Hanum, F. (2018). Exploration and collection of cucumber mosaic virus isolates of horticultural plants from Bali. International Research Journal of Engineering, IT \& Scientific Research, 
2. Detection of I-ELISA using CMV antiserum succeeded in getting $6 \mathrm{CMV}$ positive isolates namely isolates derived from cucumber plants (CMV-MB isolates), eggplant (CMV-TRB isolates) watermelon (CMV-SB isolate), chili (CMV-CB isolate), pumpkin (CMV-LB isolate) and tomatoes (CMV-TB isolates).

3. Biological test of CMV isolates from Bali, mosaic symptoms occur in the indicator plant Nicotiana glutinosa included Capsicum annuum (big chili), Cucumis sativus (cucumber), Lycopersum esculentum (tomato), and Cucurbita moschata (punpkin). Heavy mosaic symptoms only occur on Cucumis sativus (cucumber) plant. In Vigna sinensis (long bean) plant infection, CMV-Bali isolates only cause symptoms of malformation and do not even cause symptoms.

Conflict of interest statement and funding sources

The authors declared that they have no competing interest. The study was financed by Directorate of Research and Community Service, Ministry of Research, Technology, and Higher Education of the Republic of Indonesia.

Statement of authorship

The authors have a responsibility for the conception and design of the study. The authors have approved the final article.

\section{Acknowledgments}

This research was supported by the Directorate of Research and Community Service, Ministry of Research, Technology, and Higher Education of the Republic of Indonesia. We also thank our colleague, Dean of the faculty of agriculture, Universitas Mahasaraswati Denpasar, who assisted the research. 


\section{References}

Agrios, G. N. (2005). Plant pathology 5th Edition: Elsevier Academic Press. Burlington, Ma. USA, 79-103.

Fauquet, C. M., Mayo, M. A., Maniloff, J., Desselberger, U., \& Ball, L. A. (2005). Virus taxonomy. Eighth report of the international committee on taxonomy of viruses, 8, 455-465.

Francki, R. I. B., Mossop, D. W., \& Hatta, T. (1979). Cucumber mosaic virus. CMI/AAB Descriptions of Plant Viruses, No. 213.

MacNab, A. A., Sherf, A. F., \& Springer, J. K. (1983). Identifying diseases of vegetables (No. 635.0493/M169). University Park, Pa.: Pennsylvania State University, College of Agriculture.

Matthews, R. C. (2012). Fundamentals of plant virology. Academic Press.

Mochizuki, T., \& Ohki, S. T. (2012). Cucumber mosaic virus: viral genes as virulence determinants. Molecular plant pathology, 13(3), 217-225.

Palukaitis, P., Roossinck, M. J., Dietzgen, R. G., \& Francki, R. I. (1992). Cucumber mosaic virus. In Advances in virus research (Vol. 41, pp. 281-348). Academic Press.

Pandawani, N. P., Hanum, F., \& Suryani, N. N. (2017). Resistance Test of Several Varieties and Critical Phase for Cucumis Sativus towards Cucumber Mosaic Virus Infectio. International Research Journal of Engineering, IT and Scientific Research, 3(6), 66-73.

Pandawani, N. P., Javandira, C., \& Hanum, F. (2018). Exploration and collection of cucumber mosaic virus isolates of horticultural plants from Bali. International Research Journal of Engineering, IT \& Scientific Research, 4(6), 44-54. https://doi.org/10.21744/irjeis.v4n6.340 


\section{Biography of Authors}

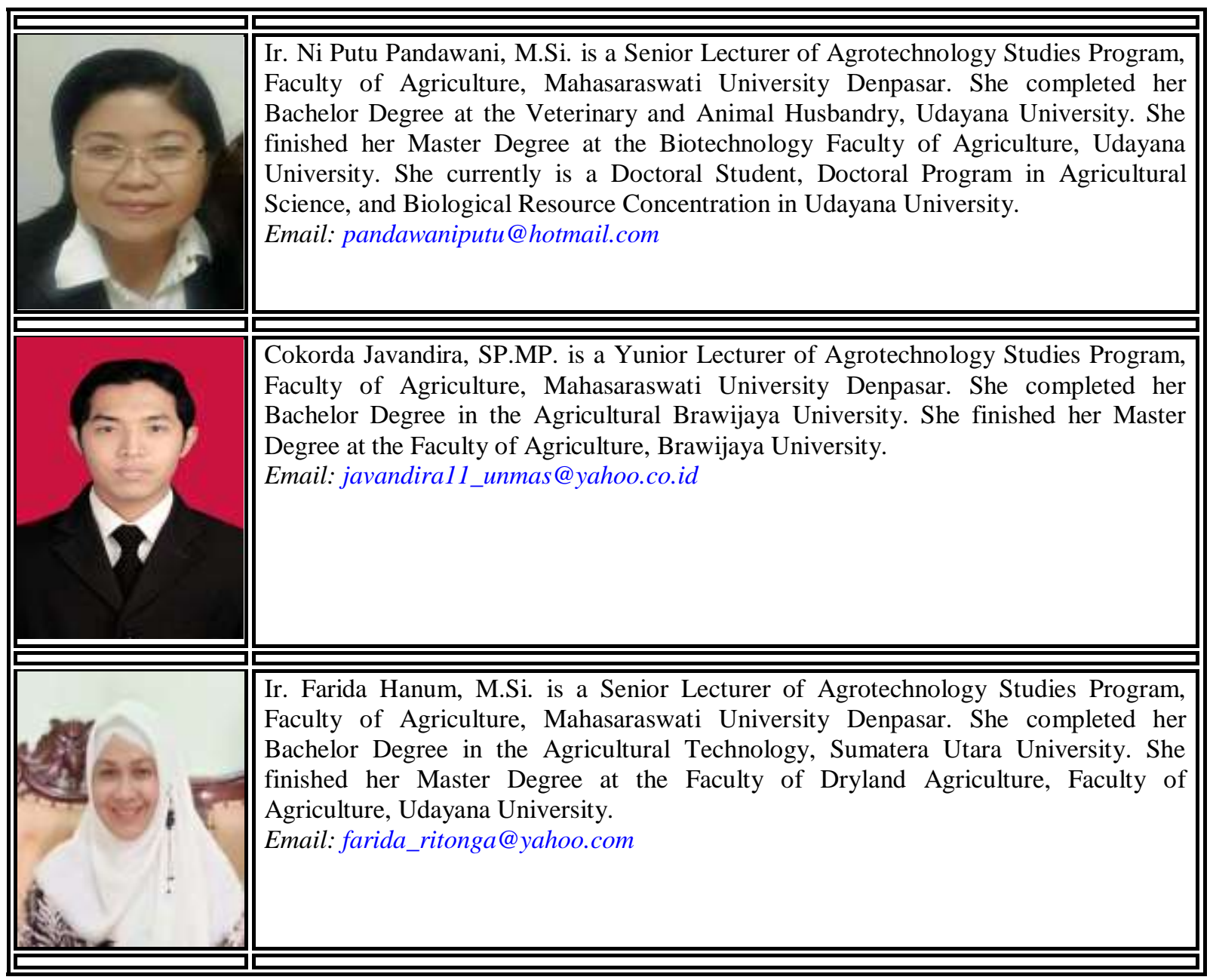

